\title{
Soils Typology and Floristic Diversity of the Forest of the "Cité Scientifique" of Brazzaville, Congo
}

\section{Jean de Dieu Nzila1,2*, Victor Kimpouni ${ }^{1,2 *}$, Noël Watha-Ndoudy ${ }^{2,3}$, Michèle Mercia Nanitelamio ${ }^{4}$, Yallo Mouhamed Salisou' ${ }^{2}$, Diane Prudence Nguila-Ntsoko²}

\author{
${ }^{1}$ École normale supérieure, Université Marien Ngouabi, Brazzaville, Congo \\ ${ }^{2}$ Institut national de recherche forestière (IRF), Brazzaville, Congo \\ ${ }^{3}$ Faculté des sciences et techniques, Université Marien Ngouabi, Brazzaville, Congo \\ ${ }^{4}$ École nationale supérieure d'agronomie et de foresterie, Université Marien Ngouabi, Brazzaville, Congo \\ Email: *jddnzila@yahoo.fr, *vkimpouni@yahoo.com
}

How to cite this paper: Nzila, J.D., Kimpouni, V., Watha-Ndoudy, N., Nanitelamio M.M., Mouhamed Salisou, Y. and Nguila-Ntsoko, D.P. (2018) Soils Typology and Floristic Diversity of the Forest of the "Cité Scientifique" of Brazzaville, Congo. Open Journal of Ecology, 8, 286-304.

https://doi.org/10.4236/oje.2018.84018

Received: February 7, 2018

Accepted: April 27, 2018

Published: April 30, 2018

Copyright $(9) 2018$ by authors and Scientific Research Publishing Inc. This work is licensed under the Creative Commons Attribution International License (CC BY 4.0).

http://creativecommons.org/licenses/by/4.0/

\begin{abstract}
A study of the typology of soils and floristic diversity was carried out in the forest of the "Cité Scientifique" of Brazzaville. The study aimed to assess the influence of soil cover on the distribution of taxa. The study covers 18 plots of $625 \mathrm{~m}^{2}$ each, distributed in different soil profiles. The floristic inventory concerns the measurement of diameter of trees with $\mathrm{dbh} \geq 10 \mathrm{~cm}$ and the counting of herbaceous and shrubs of $\mathrm{dbh}<10 \mathrm{~cm}$. The floristic composition reveals a total of 129 plant species distributed in 48 families dominated by $\mathrm{Fa}$ baceae and a preponderance of pioneer taxa. The Jaccard coefficients of similarity reveal a low degree of homology of woody plots, whereas for the flora as a whole, the floristic composition is heterogeneous. The Shannon biological diversity index of ligneous varies from 0.6 to 2 , against a maximum diversity of 0.69 to 3 . The Pielou index of ligneous ( 0.5 to 0.9 ) does not reveal any dominance. Soil cover consists of ferrallitic and podzol soils. Their texture is sandy, weakly structured, fragmentary polyhedral throughout the profile, but lumpy and/or nuciform at the surface and sub angular in depth. The porosity decreases proportionally with the depth and thickness of the horizons. The floristic analysis presents an ecosystem with a low degree of diversification for a high floristic richness. The preponderance of anthropization markers is a proof of its very advanced state of disturbance. The study shows that soil cover does not influence the distribution of timber. Indeed, the establishment and development of pioneer species are less prone to soil properties.
\end{abstract}

\section{Keywords}

Congo, Soil Cover, Floristic Diversity, Urban Forest, Biological Diversity Index, 
Distribution of Taxa

\section{Introduction}

Forest ecosystems cover between 2.4 and 6 billion hectares worldwide and those in the Congo Basin account for about 227 million ha [1]. In Congo, forest cover is equivalent to $65 \%$ of the national territory, either 22 million ha. Forests and forest soils provide environmental essential, complex and interactive functions [1]. Soils support trees and, together, help regulate important ecosystem processes through nutrient uptake, decomposition of organic matter, and water availability.

Notwithstanding the assumed roles and functions, the relational complexity, the correlation between soils and forests is not sufficiently mentioned in the studies. Soils and forests are intimately linked and mutually exert a reciprocal influence. Together, they impact the immediate environment. The positive effects of this relationship help to preserve health and ensure a healthy environment; improve livelihoods in rural areas, and climate change through carbon storage [1].

Despite the vital functions inherent in human survival, Congolese soils and forests are undergoing irreversible degradation and significant land regression due to anthropogenic actions (poorly adapted agricultural practices, clear-cutting of trees, fires recurring bush, urbanization, the establishment of infrastructures, etc.). This situation, which is very worrying, now affects some forest islets found in the south of Brazzaville city. These islets are a result of the degradation of the original forest of "Patte d'Oie", a particular and unique forest ecosystem previously found in Brazzaville. Indeed, several species are threatened with extinction within these ecosystems, or even themselves. This vision is more than plausible with the establishment of artificial forest facies based on allochthonous species.

Although the Republic of Congo has adopted adequate regulations, notably the law $n^{\circ} 003 / 91$ of 23 April 1991 on environmental protection and law $n^{\circ}$ $16-2000$ of 20/11/2000 on the Forest Code, the future of the forest islet of the "Cité Scientifique" of Brazzaville remains worrying with the increase of anthropogenic pressure (collection of wood energy and phytotherapeutic products, recurrent bush fires, deforestation leading to soil degradation, snail collection, etc.).

Recurrent bush fires and excessive deforestation lead to soil degradation that ipso facto affects the development and resilience of the forest ecosystem. This vision is more than plausible with the establishment of artificial forest facies based on non-native species as shown by the work of Kimpouni et al. [2] [3].

Despite the threats to the urban islets of natural forests and the proven services to the community, these ecosystems have still not received the attention they deserve, especially after the disappearance in Brazzaville of the forests of Tsiémé, 
Glacière Chad Ravine and Corniche, without any floristic trace [2] [3]. After collection and analysis of the floristic data of said islets, a strict defensiveness was imposed in order to preserve and reconstitute them naturally. Taking into account that soil is a resultant of biocenosis and bedrock interactions, the degradation of phytocenosis has negatively influenced its evolution. In view of their state of degradation, the challenge of safeguarding the remains of the Patte d'Oie requires a strict defensiveness whose object focuses on the floristic dynamics and the evolution of the soil cover over time. The results of this study correspond to the initial data of a global research which aims to improve the knowledge on the specific and ecosystem diversity of the Congo, in particular of mesophilic and tropophilous forests, through a typical mesh of soils and floristic distribution in the forest islet of the "Cité scientifique".

The objective of this study is to improve the knowledge of the specific and ecosystemic diversity of the Congo, in particular of the mesophilic and tropophilic forests, through a typical mesh of soil and floristic distribution in the forest islet of the "Cité scientifique".

\section{Materials and Method}

\subsection{The Study Site}

The "Patte d'Oie" forest reserve of Brazzaville, represents a particular element of the urban landscape. Its initial area fixed by the decree of the Governor-General of French Equatorial Africa (AEF), n 3037 of 13 August 1938, was 240 hectares of peri-urban natural forest. Due to the extent of the anthropogenic activities, it was reduced to 118 hectares by Order $\mathrm{n}^{\circ} 2789 / \mathrm{SF}$ of 4 December 1951. In 13 years, the reserve is imputed $51 \%$ of the initial area. With a view to its conservation, reforestation carried out in 1995 made it possible to increase this area slightly from 118 hectares to 136.52 hectares.

In order to consolidate what has been gained, the State has decided to classify a large portion of the "Patte d'Oie" forest by Decree n 2009-149 of 8 May 2009, classifying the area of the Forest Reserve of the "Patte d'Oie". The area of the classified domain is 94.55 hectares, with less than 10 ha of natural forest. The natural forest resulting from the degradation of the forest of the "Patte d'Oie" is presented in three islets, among which that of the Scientific City of Brazzaville or the "Cité scientifique" of Brazzaville [2] [3].

The experimental site is the forest of the "Cité Scientifique de Brazzaville" ex-Orstom forest. Located in the south-east of Brazzaville ( $4^{\circ} 16^{\prime} \mathrm{S}$ and $\left.15^{\circ} 14^{\prime} \mathrm{E}\right)$, its area is about 24.3 hectares. This forest grows on a plateau on the psammitic soil and whose altitude oscillates between 279 and $323 \mathrm{~m}$ (Figure 1). This relic of the forest of the "Patte d'Oie" developing in the middle of the popular district presents a high level of degradation. Notwithstanding the fact of its location, it served as a laboratory of life-size experimentation whose corollaries are declined in a floristic enrichment in exotic and local species not originating from this area. 
Designated Low-Congolese, the climate is characterized by moderate rainfall of about $1300 \mathrm{~mm} /$ year (Figure 2). The rainfall rhythm alternates between a very dry and fresh season from 4 to 5 months (June to September) and a warm and humid season (October to May). The lowest temperatures are observed in the dry season (from July to August). They are between $23.7^{\circ} \mathrm{C}$ and $24.2^{\circ} \mathrm{C}$, whereas the annual average is around $25^{\circ} \mathrm{C}$ [4] [5].

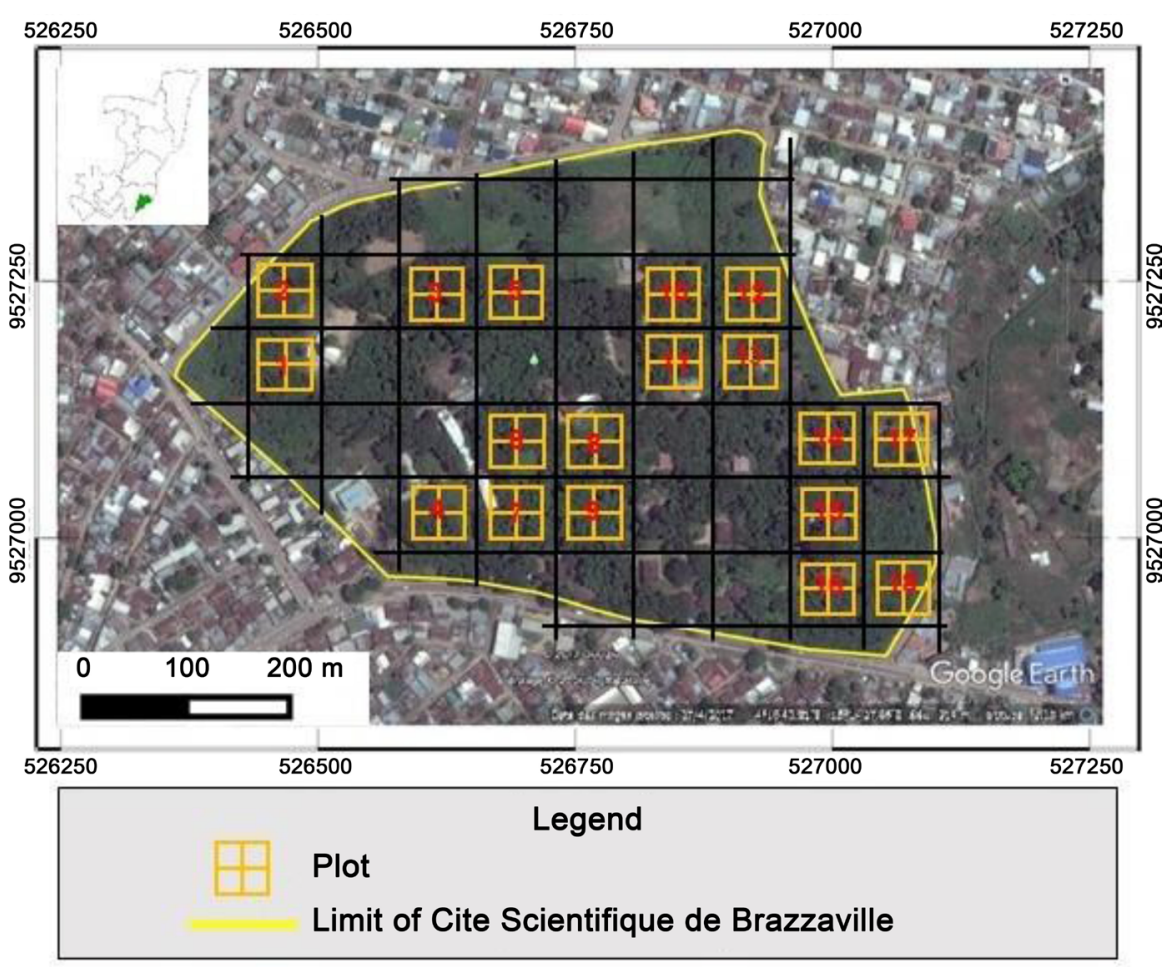

Figure 1. Localization of the site and, sampling device floristic and soil.

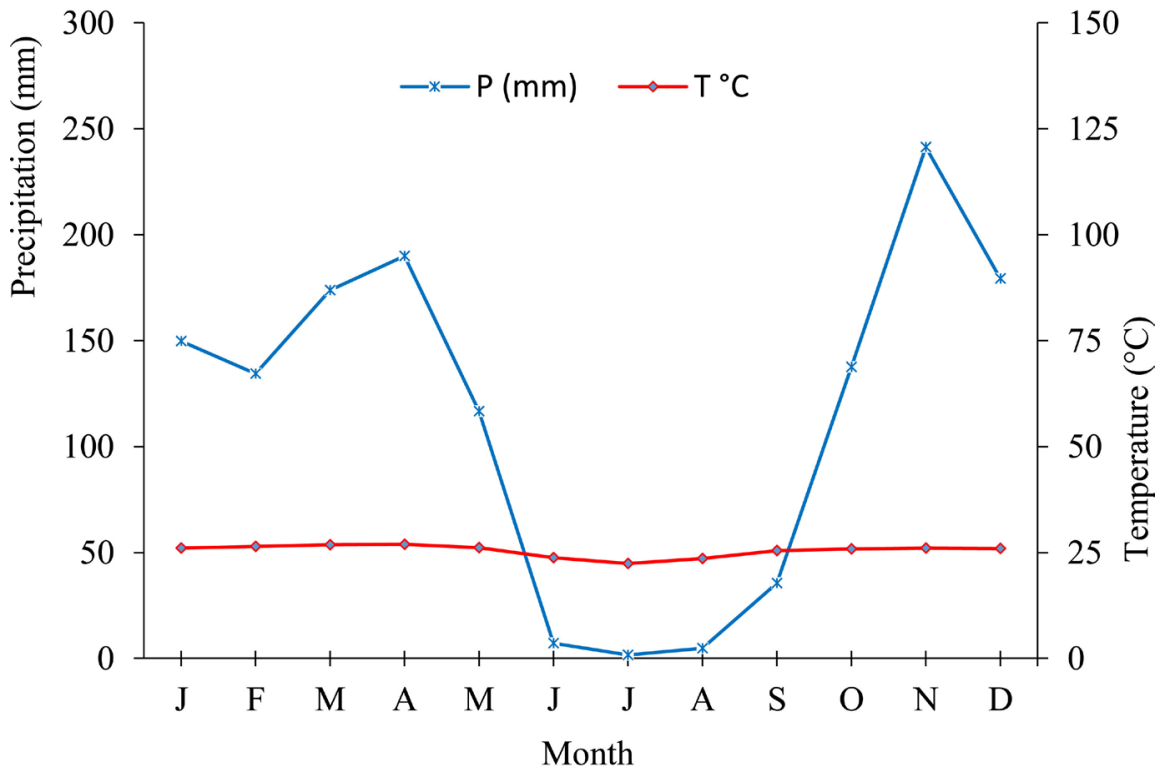

Figure 2. Brazzaville ombrothermal diagram. 
The soils of Brazzaville have developed on a variety of materials originating essentially from three major sedimentary series [6] [7] [8]. From the base to the summit, they are as follows: 1) the Inkisi series which appears in the south of Brazzaville along the Congo River where it is widely represented in the region of Boko and in tatters in the region of Mpassa [6] [7]. It rests in angular unconformity on the series of the Mpioka; 2) the sandstone series of the Stanley Pool dates from the Cretaceous period and rests unconformably on the Inkisi sandstones of the Precambrian; 3) the Batéké plateau series of tertiary age comprises two levels ( $\mathrm{Ba} 1$ and $\mathrm{Ba} 2)$ corresponding respectively to the polymorphic (Paleogene) and the ocher (Neogene) sandstones. The Brazzaville soils have a very varied texture and are generally sandy or sandy-clay. They are poor in organic matter [9] [10] and can be divided into four classes: a) podzols, b) gleysols, c) Arenosols, and d) Fluvisols [11].

The city of Brazzaville, located on the right riverbank of the Congo River, is dependent on rivers of different sizes [12] [13]. They are: 1) Djiri River in the North; 2) Tsiémé River and its tributary the Mikalou River; 3) Mfoa River and Madoukoutsékélé River in the center; 4) Djoué River and its affluent the Mfilou River.

The vegetation of Brazzaville department is none other than that of the "plateaux Teké" described by Makany [14]. It is dominated by low-shrub savannahs, sometimes steppe-like and forest in the form of islets or gallery forests. In Brazzaville, the artificial forest of the "Patte d'Oie" consists largely of Eucalyptus sp., Acacia sp., Pinus sp., While that of the "Cité Scientifique" and the forest reserves of Djiri and Loua are of relicts of the original natural forest.

\subsection{Materials}

The ecological data took place from March to April 2016. During this inventory, the herbal sheets was constituted and deposited at the national herbarium (IEC) in Brazzaville. Species identification was done in situ for the most common and ex situ in the IRSEN laboratory compared to the IEC herbariums and diagnoses of Pauwels [15], the volumes of Gabon's flora, Cameroon and the Spermaphyte flora of Congo-Belge-Rwanda-Urundi. The ordination adopted is APG IV (Angiosperm Phylogeny Group [16]) and the taxonomic nomenclature is that of Lebrun and Stork [17].

\subsection{Method of Study}

To ensure a perfect mesh between the floristic distribution and the soil types, the study area is plotted in $25 \times 25 \mathrm{~m}$ plots (either $625 \mathrm{~m}^{2}$ ). Taking into account the high degree of anthropization of the site [2] [3] [18], 18 more or less homogeneous plots representing an area of $1250 \mathrm{~m}^{2}$ were selected (Figure 1). The floristic inventory and the soil study were carried out within the same plots. A cartographic representation of the site was established in Universal Transverse Mercator (UTM) coordinates to facilitate the location of study plots. 


\subsubsection{Floristic Inventory}

This inventory consists mainly of the census and enumeration of all the floristic diversity. All trees with diameter at breast hight (dbh) greater than or equal to 10 $\mathrm{cm}$ were identified and their diameter measured. The shrubs of dbh less than or equal to $10 \mathrm{~cm}$, the creepers and herbaceous plants were identified and counted. About herbaceous plants, only presence was noted.

In addition to the floristic inventory, a more or less exhaustive mapping of the spatial distribution of the flora was carried out. It was based on the dominant species.

\subsubsection{Results Analysis Methods}

The floristic inventory data will be treated through the Jaccard similarity coefficient, the Shannon biodiversity indices and the equilibrium index or the regularity index of Pielou.

\section{1) Jaccard similarity coefficient}

This coefficient makes it possible to evaluate the similarity between two plant communities [19] [20]. It is distinguished by the fact that it gives the same quotation to the presence and absence for the species [21].

$$
\text { Jaccard }(S \%)=100 \times[C /(A+B-C)]
$$

With $A=$ number of species in the first plot, $B=$ number of species in the $2^{\text {nd }}$ plot, $C=$ number of species common to both plots.

\section{2) Shannon and Weaver Diversity Index}

This index makes it possible to better appreciate the floristic diversity taking into account the number of species and their abundance [19] [22] [23] [24].

$$
H^{\prime}=-\sum_{i=1}^{S} p_{i} \ln p_{i}
$$

$I=$ species, $p_{i}=n_{i} / N$, where $n_{i}=$ the number of individuals of the species and/or family and $N=$ total number of individuals, of all species combined, $\mathrm{Ln}=$ natural logarithm.

\section{3) Maximum diversity}

The maximum floristic diversity provides information on the diversity that a plant community can achieve, in the case of a homogeneous distribution of the individuals constituting the flora [19] [22] [25]

$$
H_{\max }^{\prime}=\operatorname{Ln}(S)
$$

With $S=$ total number of species; $\operatorname{Ln}(S)=$ the maximum specific diversity of Shannon [21].

\section{4) The index of regularity or Pielou Index}

The regularity or Pielou index (equitability) is the ratio of the Shannon diversity index to the maximum diversity index [19] [26] [27] [28]. It expresses the distribution of species within the association [2] [29]. When the index is low, it expresses a dominance of at least one taxon. There is no dominance when it is high. 


$$
J=H^{\prime} / H_{\max }
$$

\subsection{Soil Morphology}

The soil profile data was obtained in May and July 2016. In order to appreciate the spatial heterogeneity of the flora and of the different soil types, a soil pit placed in the centre of the plot was described. As for the floristic inventory, 18 soil pits have been described (Figure 1). The main characteristics used for soil horizon description are: colour with Munsell chart, texture by feeling test of soil's constituents, structure by separation of aggregates, consistence, porosity with magnifying glass, biological activity, depth and boundary [11] [30].

\subsection{Data Processing}

For mapping of soil cover and floristic distribution, each plot is georeferenced. The database includes geographic coordinates, soil type and dominant plant communities. To obtain raster maps, the special association approach used is the interpolation by Inverse Distance Weighting (IDW) method on QGIS software [31].

\section{Results}

\subsection{Floristic Composition}

The total inventory shows a total of 129 plant species belonging to 48 families. The most important families are Fabaceae (21 species, 43.75\%) followed by Rubiaceae (11 species, $22.91 \%$ ), Connaraceae (6 species, $12.5 \%$ ), Lamiaceae and Phyllanthaceae (5 species, 10.41\%). The remainder of the families making up the majority have a contribution of about 1 to 4 species.

The floristic composition of trees with $\mathrm{dbh} \geq 10 \mathrm{~cm}$ shows 501 individuals, the vast majority of which are pioneer species (Table 1). The most abundant species are: Caloncoba welwitschii with 140 individuals (27.97\%); Markhamia tomentosa with 84 individuals (16.77\%); Millettia eetveldeana with 38 individuals (7.58\%); Chaetocarpus africanus with 28 individuals (5.59\%); Senna spectabilis with 27 individuals (5.39\%); Millettia laurentii with 23 individuals (4.59\%). The least represented are: Acacia auriculoformis with one individual (0.20\%); $\mathrm{Hy}_{\text {- }}$ menaea courbaril with 2 individuals (0.40\%); Albizia adianthifolia with 3 individuals (0.60\%), Paramacrolobium coeruleum with 4 individuals (0.80\%).

\subsection{Diameter Size Distribution}

The distribution of trees in different diameter sizes shows a very important regenerative cohort supporting sufficient natural regeneration. However, a detailed analysis of this population reveals a low rate of individuals characteristic of forest ecosystems. In the case of this forest islet of the "Cité scientifique", the markers are Millettia eetveldeana, Bosqueiopsis gilletii, Strychnos variabilis, Dracaena arboreus, Antiaris toxicaria and Syzygium brazzavillense, each of which gives an erratic curve with very few individuals in the first diameter classes. 


\subsection{Indices of Biological Diversity}

The Shannon Index ranges from 0.60 to 2.22 with an average of $1.62 \pm 0.15$. However, the maximum diversity index oscillates from 0.69 to 3 for an average of $2.02 \pm 0.11$. As for fairness, it is between 0.50 and 0.96 , which is an average of $0.80 \pm 0.19$.

\subsection{The Similarity Coefficient}

The coefficient of similarity of Jaccard holding dbh tree counts $\geq 10 \mathrm{~cm}$, denotes 6 records for 3 pairs including: 2 and 18, 4 and 7, 5 and 8 whose value is between $50 \%$ and $58.3 \%$. For the rest of the combinations, the values are between 0 and $45.5 \%$. However, based on total floristic diversity (woody and herbaceous), values range from $6.90 \%$ to $37.70 \%$ for all combinations. These values being less than $50 \%$ between plots, the floristic composition of each is an entity in its own right.

\subsection{Cartography of the Flora}

According to the zones of dominance observed and confirmed by the floristic inventory and the indices of biological diversity, 17 sub-facies can be identified (Figure 3). The analysis of the floristic composition reveals an exceptional dominance of the pioneer taxa, bio-indicators of the secondarization of the ecosystem. The zones where Millettia laurentii and/or Paramacrolobium coeruleum are predominant, result from the anthropization of the environment. These two taxa, which are not native to the "Patte d'Oie" forest, are intensively introduced into the "Cité Scientifique" forest.

\subsection{Morphological Characteristics of Soils}

The soils of the "Cité Scientifique" have the typical characteristics of Arenosols and Podzols. Generally deep with a variation in color ranging from very dark brown to yellowish brown, a sandy texture, a lumpy structure on the surface and polyhedral in depth. They are well drained and have a high porosity, especially in the first 20 centimeters. The litter with a thickness of 3 to $9 \mathrm{~cm}$, favoured the formation of a deep humiferous horizon, up to $120 \mathrm{~cm}$ of depth. These morphological characteristics distinguish three types of soil: Ferralic Arenosols, Albic Arenosols, and Podzols (Figure 4).

\subsubsection{Ferralic Arenosols}

This type covers almost $55 \%$ of the area of the "Cité Scientifique" of Brazzaville (Figure 1 and Figure 4). The soil profile is of type O-A11-A12-B1-B2. The organic horizon (litter) has an average thickness of $4.6 \mathrm{~cm}$ and consists of decomposed organic debris of moder type. The A1 or A11 humiferous horizon has an average thickness of $49 \mathrm{~cm}$ and the color varies according to the profiles of very dark brown (10YR 3/2) to dark yellowish brown (10YR 4/4). At the accumulation horizon $B$ the color is brownish yellow (10YR 6/6). The texture is sandy for all profiles. The soil profile description: 


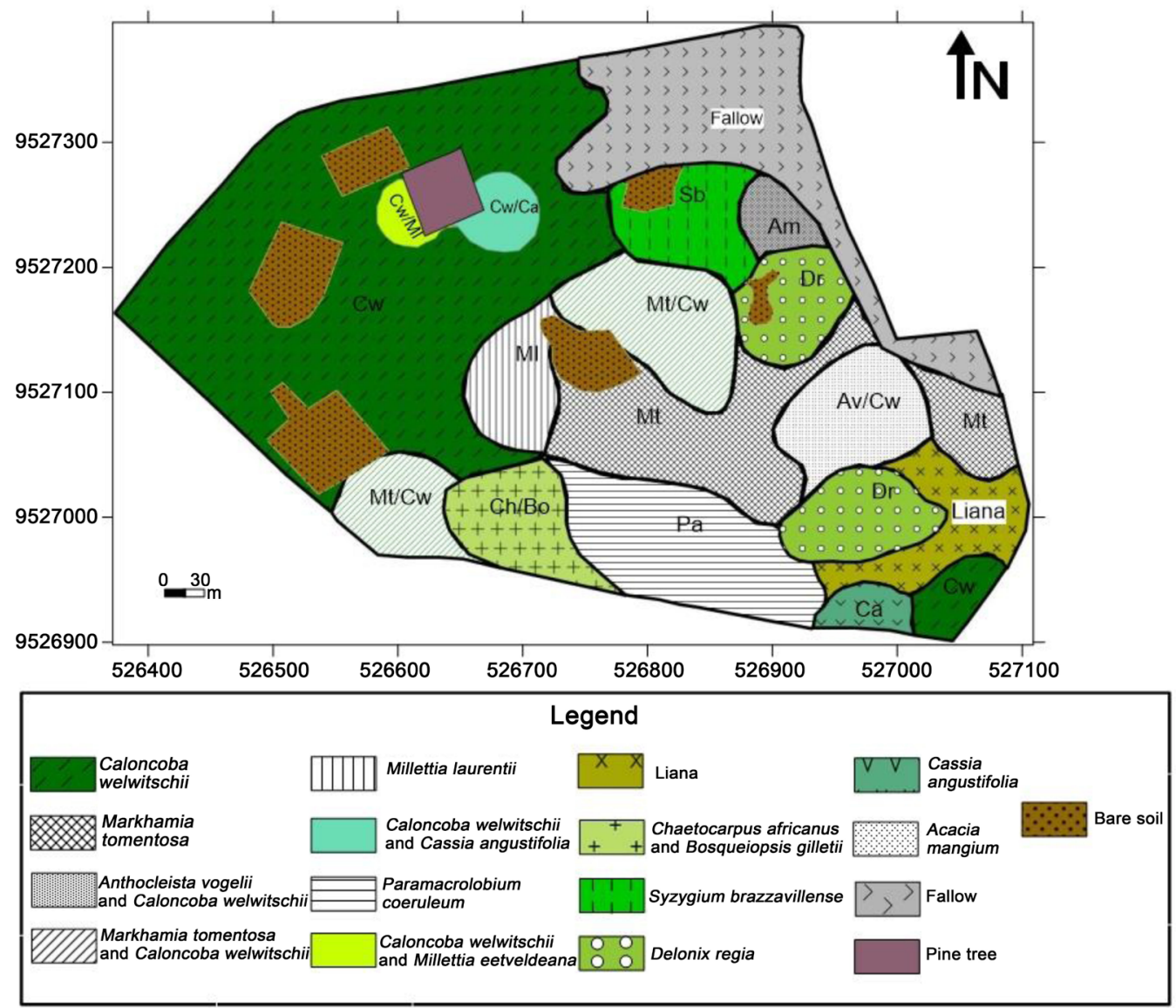

Figure 3. Spatial distribution of dominant plant communities within the study area.

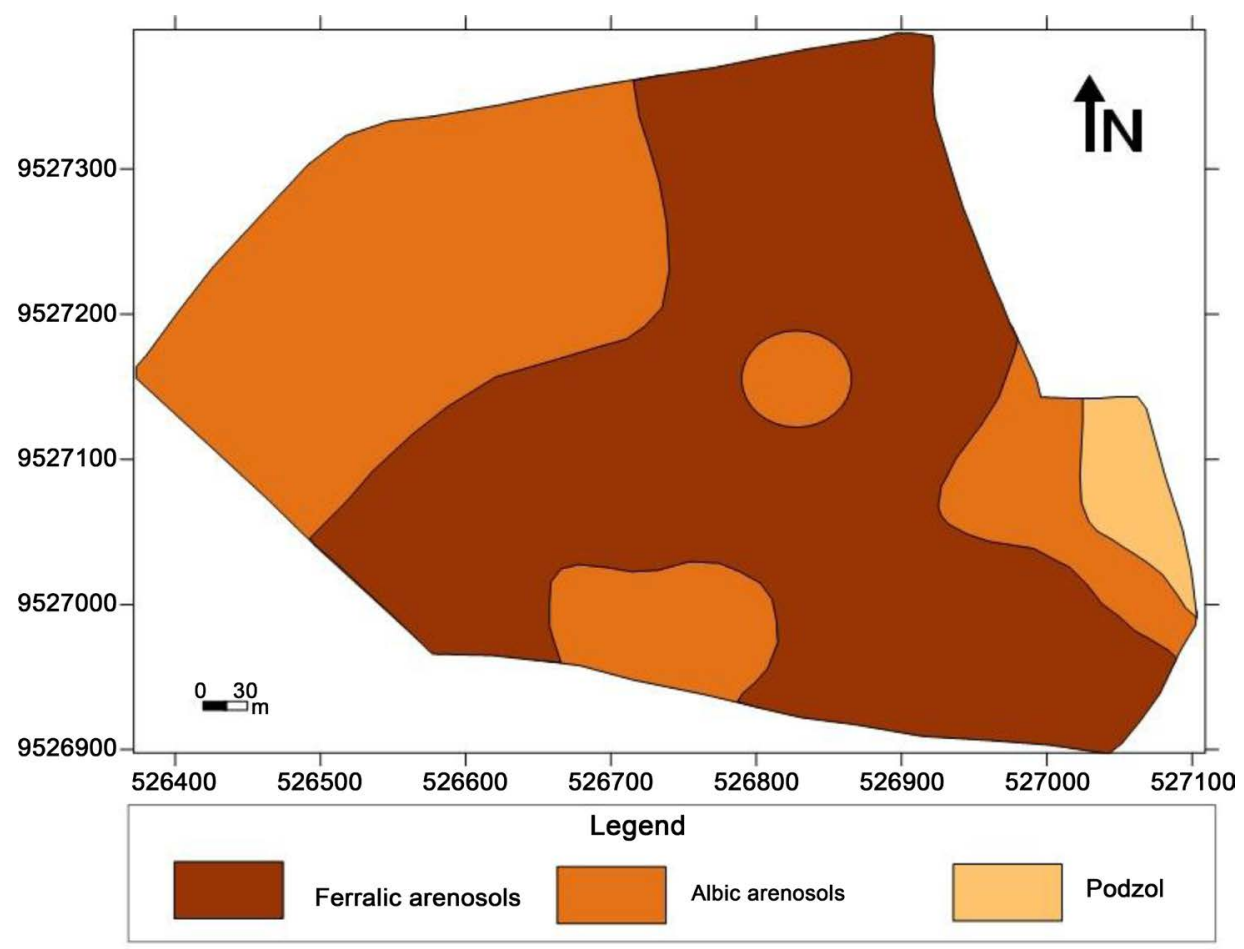

Figure 4. Spatial distribution of soil types within the study area. 
0 - $5 \mathrm{~cm}$ (O horizon): moder litter type, dominate by organic material consisting of undecomposed and partially decomposed litter, such as leaves and twigs, and whole decomposed litter (humus). Many biological activities (termite, ants, channels and other insect activities). Abrupt boundary.

5 - $30 \mathrm{~cm}$ ( $\mathrm{A}_{11}$ horizon): dark brown (10 YR 3/3). Sandy texture weak to moderate structure with very fine to fine subangular blocky. Friable material. High porosity and common roots. Common biological activity (termite and ant channels). Clear boundary.

30 - $90 \mathrm{~cm}$ ( $\mathrm{A}_{12}$ horizon): brown (10 YR 5/3). Sandy texture. Weak to moderate structure with very fine to medium subangular blocky. Friable material. High porosity and few roots. Common biological activity (termite and ant channels and nests). Clear boundary.

$90-110 \mathrm{~cm}$ ( $B_{1}$ horizon): yellowish brown (10 YR 5/6). Sandy texture. Weak to moderate structure with fine to coarse subangular blocky. Medium porosity and few roots. Few biological activity (insect channels). Gradual boundary.

110 - $200 \mathrm{~cm}$ ( $\mathrm{B}_{2}$ horizon): brownish yellow (10 YR 6/6). Sandy texture. Weak to moderate structure with medium to coarse subangular blocky. Medium porosity and few roots.

\subsubsection{Albic Arenosols}

This type of soil has the same morphological characteristics as the typical Ferralic Arenosols. They are differentiated at the level of the A horizon which has traces in the form of bleached sandy beaches called leached. These soils are characterized by high permeability and extreme poverty in minerals.

$44.44 \%$ of the area of the Scientific City of Brazzaville is classified as leached ferrallitic (Figure 1 and Figure 4). The A horizon, whose color varies, according to the profiles, from very dark gray brown (10YR 3/2) to dark yellowish brown (10YR 4/4), has an average thickness of $40.75 \mathrm{~cm}$. The soil profile description:

0 - $5 \mathrm{~cm}$ (O horizon): moder litter type, dominate by organic material consisting of undecomposed and partially decomposed litter, such as leaves and twigs, and whole decomposed litter (humus). Many biological activity (termite, ants, channels and other insect activities). Clear boundary.

5 - $50 \mathrm{~cm}$ (A horizon): dark greyish brown (10YR 4/2). Sandy texture. Weak structure with very fine to medium friable subangular blocky. Few biological activity (termites, insect channels). Common porosity and roots. Clear boundary.

$51-120 \mathrm{~cm}$ ( $\mathrm{B}_{1}$ horizon): yellowish brown (10YR 5/4). Sandy texture. Weak to moderate structure with fine to coarse subangular blocky. Few biological activity (insect channels). Common porosity and very few roots. Gradual boundary.

$120-200 \mathrm{~cm}$ ( $\mathrm{B}_{2}$ horizon): brownish yellow (10YR 6/8). Sandy texture. Weak to moderate structure with fine to coarse subangular blocky. Few biological activity (insect channels).

\subsubsection{Podzols}

They cover $5.56 \%$ of the area of the Scientific City of Brazzaville and are located 
on the slope of a valley. The brown fibrous litter is of the mor type. The whole profile presents: a generally particulate structure, a sandy texture and high porosity, and a diffuse transition between horizons. The depleted humic horizon is dark gray (10YR 4/1). Within the E horizon there is a succession of intersecting bands of accumulation of organic matter (horizon Bh). All soils types are a granular structure in the topsoil and blocky subangular structure in the deep horizons. The soil profile description:

$0-6 \mathrm{~cm}$ (O horizon): mor litter type, dominate by undecomposed very fine roots and whole decomposed litter (humus). Few biological activity (insect channels). Abrupt boundary.

6 - 50/80 cm ( $A_{11}$ horizon): dark grey (10YR 4/1). Sandy texture. Weak structure with very fine to medium subangular blocky. Few biological activity (insect channels). Common roots and porosity. Gradual and irregular boundary.

$50 / 80-110 / 120 \mathrm{~cm}$ ( $A_{12}$ horizon): grey (10YR 6/1). Sandy texture. Weak structure with very fine to medium subangular blocky. None biological activity. Gradual and irregular boundary.

110/120 - 200 (E horizon): white (10YR 8/1). Sandy texture. Few roots and common porosity.

\subsection{Mapping Soil Cover and Floristic Distribution}

Analysis of the distribution of taxa in relation to soil cover does not reveal a close relationship between the type of soil and any species, which are intimately subordinated (Figure 5).

\section{Discussion}

\subsection{Floristic Analysis}

The forest of the "Cité scientifique" develops on ferrallitic and podzolic soils from Batéké sand [9]. It is influenced by climatic parameters conferring concomitantly a mesophilic and tropophilic attribute, and a low degree of resilience [2] [3].

The floristic distribution observed, on each of the soil facies marking the soil cover, would be the corollaries associated with the anthropic action on this woody ecosystem. The anthropogenic level of effects is progressive from the outside to the interior of the ecosystem; thus, woody flora growing on leached and podzolic ferrallitic soil is more affected. The combined actions of climatic elements (in particular precipitation) and anthropic degradation (bush fire, clear-cut or non-clear cutting of trees, slash-and-burn crops) would be the main source that would feed the soil pedological regression process of the "Cité scientifique". Indeed, according to a scale of the level of degradation associated with the presence of climatic markers, natural or subspontaneous, one distinguishes typical ferrallitic soils (ferralic arenosols), leached ferrallitics (albic arenosols) and podzols.

Typical ferrallitic soils form the soil cover of the least disturbed forest facies. 


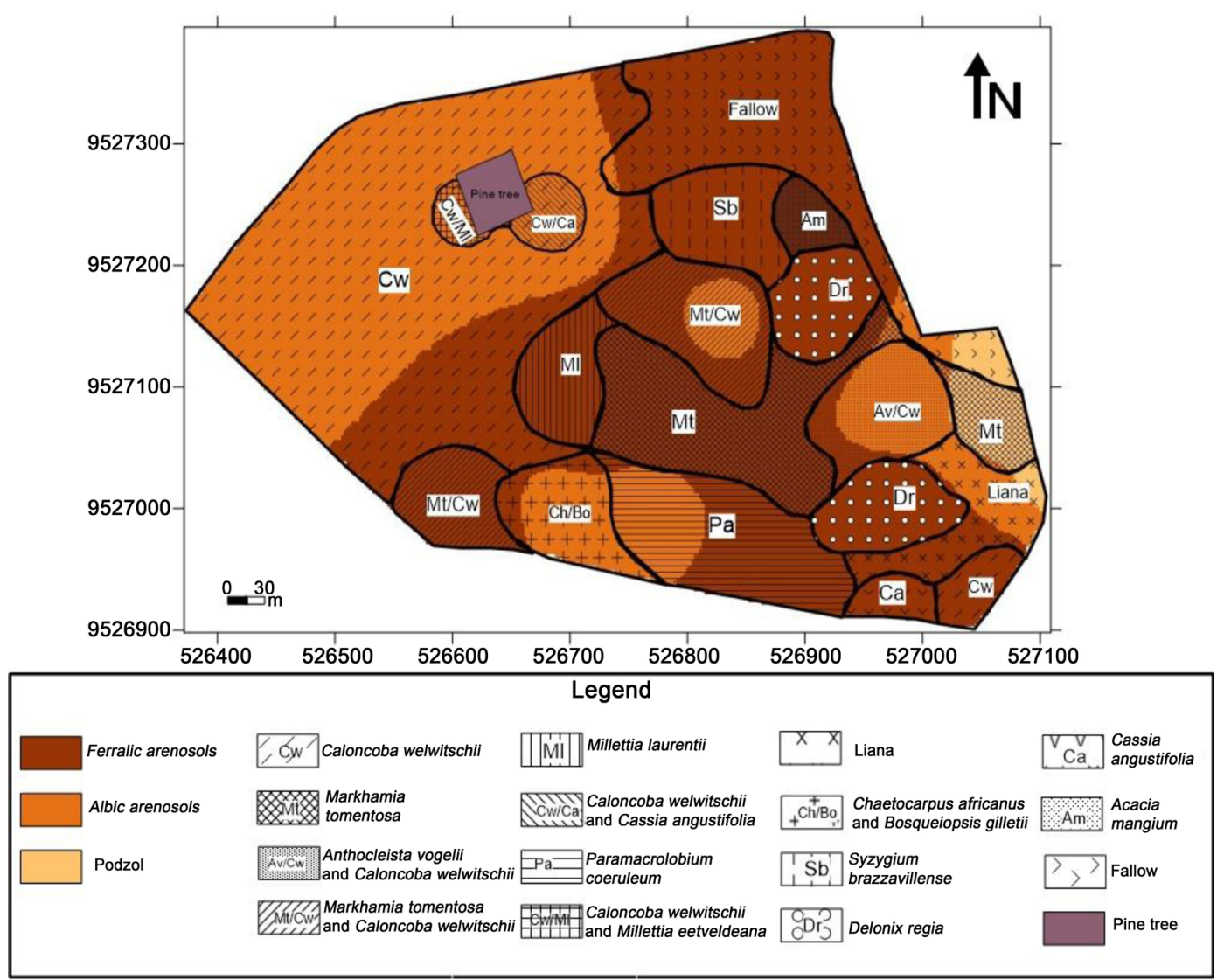

Figure 5. Mesh of soil cover and distribution of plant communities.

The floristic diversity is based on key taxa like Millettia laurentii, Bosqueiopsis gilletii, Syzygium brazzavillense, Strychnos variabilis, Dracaena arborea, Millettia eetveldeana, Delonix regia, Markhamia tomentosa, which have modest densities. A well-stocked undergrowth in Palisota ambigua, Costus afer,

The leached ferrallitic soils are home to a pioneering woody flora (heliophilous) that is clearly dominated by Caloncoba welwitschii. Chromolaena odorata is the characteristic of undergrowth with Commelina diffusa, Panicum maximum;

Podzolic soils are those with the most significant effects of anthropization. On these soils graminaceous species such as Digitaria horizontalis bioindicator of skeletal and acid soils develop. The woody ones are in very low density and most often markers of the secondarisation of the habitat.

The floristic composition of the 18 plots does not reveal any clear distinction in the spatial distribution of taxa. Despite the fact that some families are present and/or dominant only in a few plots, the distribution of species is almost the same in our study area. A detailed analysis of the shrub flora demonstrates that it is over $75 \%$ dominated by pioneer taxa, indicative of anthropogenic degradation [2] [3] [18] [32]. These include Caloncoba welwitschii, Markhamia tomentosa, Chaetocarpus africana, Hymenocardia ulmoides, Trema orientalis, Macaranga spinosa, Chromolaena odorata on the one hand, and numerous herbaceous and 
lianescent species, notably Connaraceae, on the other hand. These species are an indicator of the disturbance of forest ecosystems in the region and indicate insufficient natural regeneration [2] [3] [18].

Notwithstanding the secondary nature of this ecosystem, it combines a low degree of floristic diversification with a high specific richness. These parameters affect both the tree scale and the level of the overall floristic diversity (shrub, trees and herbaceous plants). According to data from the Pielou index, a homogeneous spatial distribution of taxa is observed globally within the forest of the "Cité Scientifique" [2] [3]. This pioneering cohort is essentially heliophilic, and has a short life span, and these species have almost no specific trophic requirements. Their development within this ecosystem is not intimately correlated with soil type. In soil and floristic cover, soils react less quickly than vegetative cover [33]. However, the degree of anthropogenic pressure is not homogeneous throughout the study area, as symbolized by the floristic variations observed between plots.

\subsection{Soil Analysis}

\subsubsection{Soil Structure and Texture}

These soils are considered to have undergone the pedogenetic phenomenon of ferrallitisation without any other secondary process, physical or chemical, intervening in such a way as to significantly modify the normal evolution. The only differentiation is due to the greater or lesser penetration of organic matter [9]. A profile consisting of a succession of horizons of relatively constant texture over the entire thickness of the ground; a relatively low organic matter content.

The most important factors in the structure of Ferralic Arenosols are the roles played by iron and organic matter. Indeed, the free iron $\left(\mathrm{Fe}^{2+}\right)$, being very active, forms stable aggregates with other minerals such as kaolinite or with organic matter forming humo-ferric complexes; and the humification of the organic matter releases the polysaccharides which allow a high cohesion of the soil structure. Thus, in Ferralic Arenosols, if iron is essential in the structure of deep horizons, it shares this role with organic matter in surface horizons [34]. This explains the difference between the structure in the surface horizons (granular) and that of the depth (blocky subangular) horizons of the soils of the site studied because these soils are well provided with organic matter [9] [10]. The structure of the surface horizons can allow a good circulation of the fluids of the soil and a good development of the plants.

The described podzol is located on a low slope glacis. This topographic position is favourable to the hydromorphic conditions necessary for the genesis of podzols known as "terraces" [10]. The texture of all the soils described is sandy. This texture is inherited from the mother rock, which consists of the formation of the Batéké sands.

\subsubsection{Soil Types and Floristic Diversity}

According to [35] [36], the relationship between soils and forests is very com- 
plex, because the two entities are interrelated and mutually influential. Together, soil and forest influence the environment as a whole.

Water availability is an important factor for soils under forest, and its circulation has physical characteristics of the substrate [33] [37] [38]. The soils of the "Cité scientifique" of Brazzaville have a sandy texture throughout the profile, which gives them a very high retention capacity. On the other hand, the rupture of the water films available to the plants intervenes very early during the dry season. In fact, when the clay content of a soil decreases, the latter less and less ensures that the water in the pores is brought into contact with the absorbent surface of the roots [34]. However, their abundance in organic matter ensures the retention of useful water in surface horizons [39].

Ferralic Arenosols, under rain forests, have a very low capacity in exchangeable bases. Their physical properties differ fundamentally depending on the nature of the parent rock and the flora has a very high specific diversity [40]. Duchaufour et al. [41] reveal that defects in leached soils are, for adult trees, the depletion of the absorbent complex of leached horizons. The corollaries are deficits in mineral and nitrogen nutrition, on the one hand, a too high compactness of the horizon B which sometimes becomes stifling in the wet season, on the other hand. This phenomenon limits the penetration of the root system in depth.

In terms of soil-plant relationships, the differentiation of ecosystems and forest types depends on the distribution of roots, the chemical characteristics of the litter, the accumulation of organic matter [33] [37] [38] [42]. The differentiation of the forest environment is linked to the characteristics of woody plants. In a tropical climax forest, the stock of accumulated organic matter allows a part of the cycle to pass through the litter and the humid horizon where the elements are directly absorbed by a dense root hair. The enrichment of the soil in organic matter, produced by the tree, increases its exchange capacity and the trapping of the mineral elements of rainfall [42] [43].

The plant can restore only what it has taken from the ground. Its intervention in the improvement of the mineral status of a soil will be done by the displacement of the mineral reserves and their conservation in the organic matter of the soil. Trees modify the characteristics of the soil in a direction that is often beneficial in the longer term, allowing them to restore degraded or depleted soil to a certain degree of fertility [38] [42].

Sabatier and Prevost [40] state that podzols are very different in vegetation from Ferralic Arenosols. This assertion, coupled with a mature ecosystem, cannot be verified in a highly anthropogenic forest dominated by pioneer species, such as that of the "Cité scientifique" [33] [37] [44].

The soil and the forest are in unstable equilibrium; they do not resist against the destructive action of man, which is at the origin of their regressive evolution [45]. The most detrimental to their development are the slash and burn agriculture, bush fires, and natural resource extraction which increase each year [46] [47]. Indeed, the pressure induced by the anthropic activities on a space contributes to 
Table 1. General floristic synoptic and soil typology.

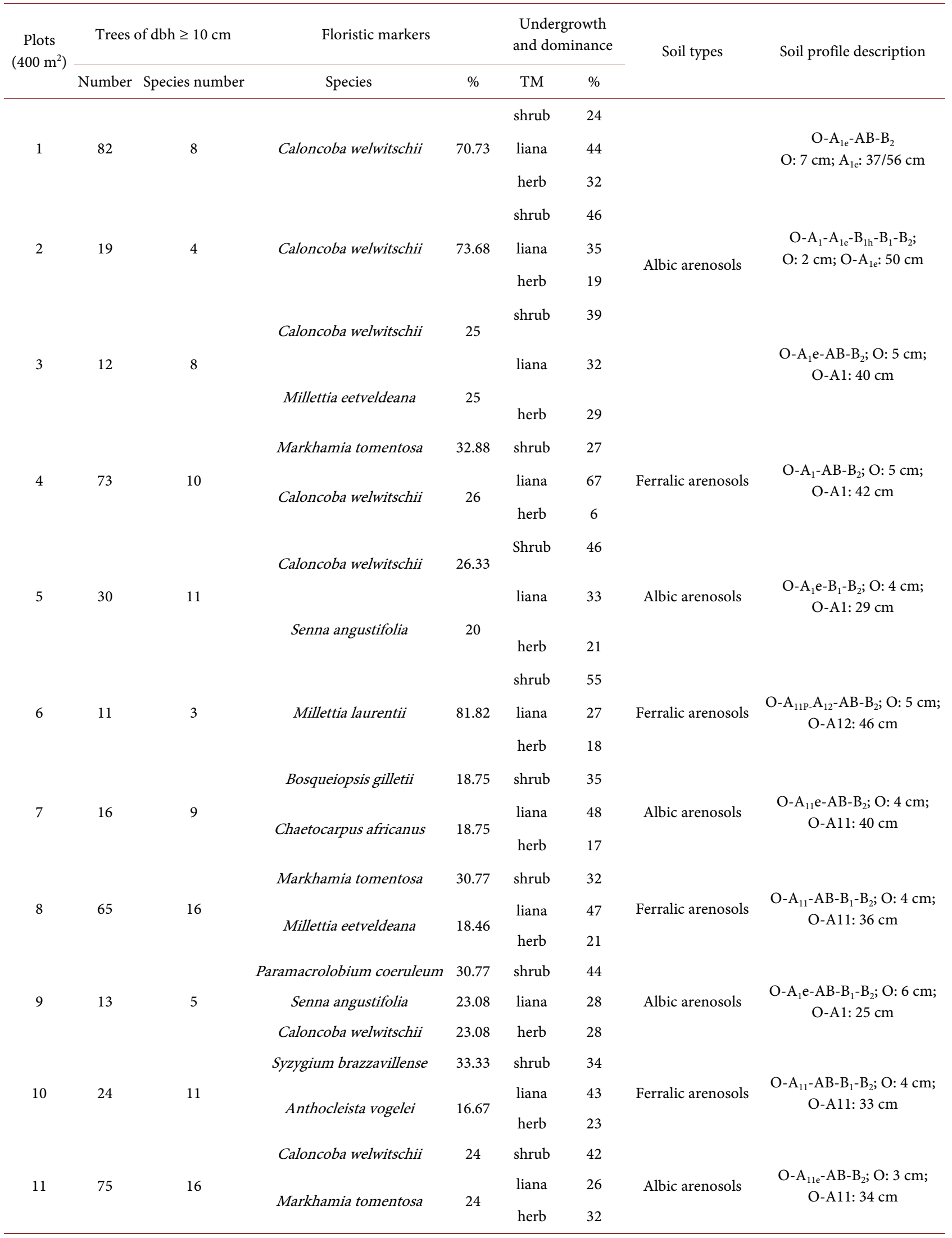




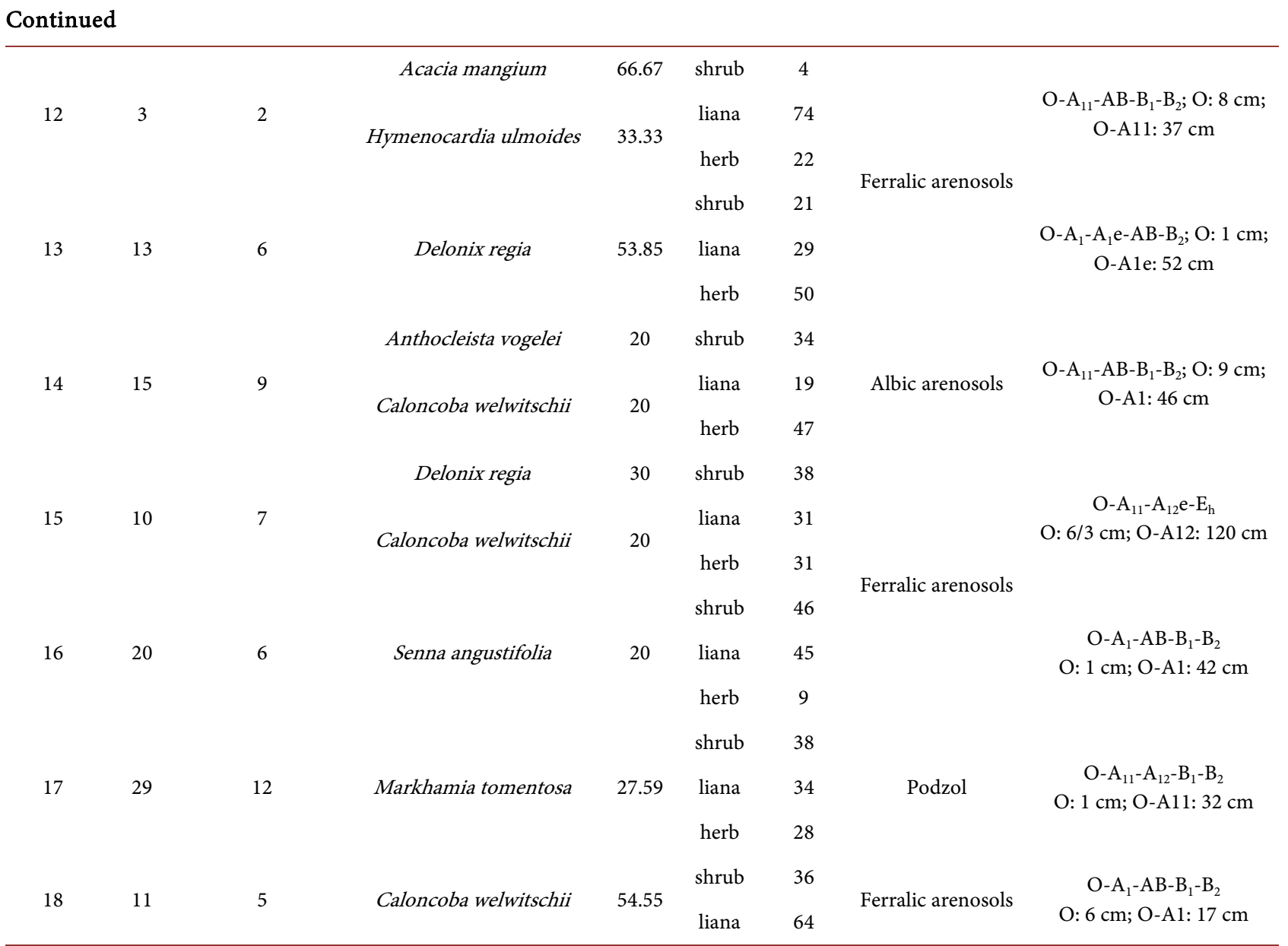

modify it, following a sequence: the occupation of the ground and the disturbance of the landscape; and vegetation dynamics [37] [38] [45].

At the present stage of the development of the forestry ecosystem of the "Cité Scientifique" and the pioneering character of its flora, the pedological cover less influences this distribution. Dominated by pioneer species, these taxa are less demanding for the physico-chemical properties of the substratum, a factor determining their spatialization [37] [38] [45].

\section{Conclusions}

The urban forest ecosystem of the "Cité scientifique" of Brazzaville has a very advanced state of anthropization. It is characterized by a floristic composition clearly dominated by the so-called heliophilic pioneer species, symbols of a beginning of the reconstitution process. The low rate of species typical of this mesophilic and tropophilous forest compared to Millettia laurentii is evidence of its tendency to become its characteristic. This observation is more plausible insofar as the variation in the magnitude of the degree of anthropogenic impact within this ecosystem creates pockets dominated by Millettia laurentii for the trees of the upper floor.

Soil cover shows two main types of soils including Arenosols and Podzols that 
undergo the pedogenetic phenomenon of ferrallitisation. By coupling the taxon distribution map and the soil cover, this mesh does not discriminate a single group of plants that are subordinate to a given soil type. The fact that the floristic cohort is dominated by the pioneer species that witness a degradation of the environment, no influence of the soil is noted on its distribution. Their settlement and development are less dependent on the physicochemical properties of the soil. That is why there is an almost homogeneous floristic distribution in this urban forest ecosystem.

\section{References}

[1] Anonyme (2014) Les forêts du Bassin du Congo: État des forêts 2013. In: de Wasseige, C., Flynn, J., Louppe, D., Hiol Hiol, F. and Mayaux, Ph., Eds., Weyrich, Belgique.

[2] Kimpouni, V., Mbou, P., Apani, E. and Motom, M. (2013) Floristic Diversity and Structural Parameters of the Brazzaville Patte d'Oie forest, Congo. Open Journal of Ecology, 3, 518-531. https://doi.org/10.4236/oje.2013.38061

[3] Kimpouni, V., Mbou, P., Gakosso, G. and Motom, M. (2013) Biodiversité floristique du sous-bois et régénération naturelle de la forêt de la Patte d'Oie de Brazzaville, Congo. International Journal of Biological and Chemical. Sciences, 7, 1255-1270. https://doi.org/10.4314/ijbcs.v7i3.31

[4] Vennetier, P. (1977) Atlas de la République Populaire du Congo. Edition Jeune Afrique, Paris.

[5] Samba-Kimbata, M.-J. (1978) Le climat Bas-congolais. Thèse de doctorat, Université de Dijon, Dijon.

[6] Cosson, J. (1955) Notice explicative sur les feuilles de Brazzaville et Pointe-Noire Carte géologique de reconnaissance au 1/500,000. Direction générale des mines et de la géologie de l'AEF, Brazzaville.

[7] Dadet, P. (1969) Notice explicative de la carte géologique de la République du Congo Brazzaville au 1/500,000. Mémoire BRGM n ${ }^{\circ} 70$, Brazzaville.

[8] Le Marechal, A. (1966) Contribution à l'étude des plateaux Batékés (géologie, géomorphologie, hydrogéologie), ORSTOM, Brazzaville.

[9] Denis, B. (1974) Notice explicative ${ }^{\circ} 52$. Carte pédologique Brazzaville-Kinkala. République du Congo à 1/200,000, ORSTOM, Brazzaville.

[10] Schwartz, D. (1987) Les sols des environs de Brazzaville et leur utilisation. ORSTOM, Pointe-Noire.

[11] FAO (2006) Guidelines for Soil Description. Fourth Edition, FAO, Rome.

[12] Louembe, D. (1986) Problème de drainage des eaux pluviales sur le site de Brazzaville, ORSTOM, AGECO. Mission française de coopération et action culturelle. Congo, Brazzaville.

[13] Moukolo, N. (1992) État des connaissances actuelles sur l'hydrogéologie du Congo. ORSTOM, Brazzaville.

[14] Makany, L. (1976) Végétation des plateaux Teke (Congo). Coll. Travaux Université de Brazzaville, Congo, Brazzaville.

[15] Pauwels, L. (1993) Nzayilu N’ti. Guide des arbres et arbustes de la région de Kinshasa-Brazzaville: Jard. Bot. Nat. Belg., Meise.

[16] APG IV (2016) An Update of the Angiosperm Phylogeny Group Classification for 
the Orders and Families of Flowering Plants. Botanical Journal of the Linnean Society, 181, 1-20. https://doi.org/10.1111/boj.12385

[17] Lebrun, J.-P. and Stork A.L. (1991-2015) Énumération des plantes à fleurs d'Afrique tropicale et Tropical African Flowering Plants: Ecology and Distribution. Vol. 1-10, Conservatoire et Jardin botaniques de la Ville de Genève, Genève.

[18] Kimpouni, V., Apani, E., Mbou, P. and Motom, M. (2014) Étude floristique des îlots forestiers naturels de la Patte d'Oie de Brazzaville, Congo. Acta Botanica Gallica, 161, 63-79. https://doi.org/10.1080/12538078.2013.870048

[19] Magurran, A.M. (2004) Measuring Biological Diversity. Blackwell Science Ltd., Oxford.

[20] Jaccard, P. (1901) Étude comparative de la distribution florale dans une portion des Alpes et du Jura. Bulletin de la Société Vaudoise des Sciences Naturelles, 37, 547-579.

[21] Legendre, L. and Legendre, P. (1984) Écologie numérique: La structure des données écologiques. 2nd Edition, Tome 2. Coll. d'écologie, 13, Masson, Paris.

[22] Jayaraman, K. (1999) A Statistical Manual for Forestry Research. FORSPA-FAO, Rome.

[23] Shannon, C.E. (1948) A Mathematical Theory of Communication. The Bell System Technical Journal, 27, 379-423. https://doi.org/10.1002/j.1538-7305.1948.tb01338.x

[24] Shannon, C.E. and Weaver, W. (1963) The Mathematical Theory of Communication. University of Illinois Press, Illinois.

[25] Marcon, E. (2014) Mesures de la biodiversité. UMR Écologie des forêts de Guyane. http://www.ecofog.gf

[26] Lloyd, M. and Ghelardi, R.J. (1964) A Table for Calculating the "Equitability" Component of Species Diversity. Journal of Animal Ecology, 33, 217-225. https://doi.org/10.2307/2628

[27] Pielou, E.C. (1966) The Measurement of Diversity in Different Types of Biological Collections. Journal of Theoretical Biology, 13, 131-144. https://doi.org/10.1016/0022-5193(66)90013-0

[28] Pielou, E.C. (1975) Ecological Diversity. Wiley, New York.

[29] Mampouya wenina, Y.E. (2015) Biodiversité et variabilité de la densité du bois des arbustes de savane dans les environs du village Mâh (Plateaux Téké, République du Congo). Mémoire d’Ingénieur, Université Marien Ngouabi, Brazzaville.

[30] FAO-WRB (2006) World Reference Base for Soil Resources 2006. A Framework for International Classification, Correlation and Communication. World Soil Resources Reports No. 103, FAO, Rome.

[31] Miller, B.-A. (2017) Geographic Information Systems and Spatial Statistics Applied for Soil Mapping: A Contribution to Land Use Management. In: Soil Mapping and Process Modelling for Sustainable Land Use Management, Elsevier, New York, 127-149. https://doi.org/10.1016/B978-0-12-805200-6.00005-0

[32] Kemadjou Mbakemi, D. (2011) Dynamique forestière post-exploitation industrielle: Cas de la forêt dense semi-décidue de Mbalmayo au sud Cameroun. Master de Géographie, Université de Yaoundé I, Yaoundé.

[33] Pomel, S. (2002) Les couvertures végétales et pédologiques de l'Afrique occidentale et centrale: Une conception anthropogène de la zonalité? Historiens et Géographes, 379, 283-296.

[34] Boyer, J. (1982) Les sols ferrallitiques, tome x, Facteurs de fertilité et utilisation des 
sols. ORSTOM, Paris.

[35] Puig, H. (2001) La forêt tropicale humide. Belin, Paris.

[36] Frontier, S., Pichod-Viale, D., Leprêtre, A., Avoult, D. and Luczak, C. (2008) écosystèmes: Structure, fonctionnement, évolution. 4 è éd., Dunod, Paris.

[37] Freycon, V., Sabatier, D., Paget, D. and Ferry, B. (2003) Influence du sol sur la végétation arborescente en forêt guyanaise: Etat des connaissances. Rev. For. Fr., 55, 60-73.

[38] Yemefack, M., Nounamo, L., Njomgang, R. and Bilong, P. (2004) Influence des pratiques agricoles sur la teneur en argile et autres propriétés agronomiques d'un sol ferrallitique au sud Cameroun. Tropicultura, 22, 3-10.

[39] Girad, M.C., Schvartz, C. and Jabiol, B. (2011) Étude des sols: Description, cartographie, utilisation. Dunod, Paris.

[40] Sabatier, D. and Prévost, F. (2003) Quelques données sur la composition floristique et la diversité des peuplements forestiers de Guyane Française. Revue Bois et Forêts de Tropique, 219, 31-55.

[41] Duchaufour, Ph., Souchier, B. and Bonneau, M. (1994) Pédologie 2: Constituants du sol. Masson, Paris.

[42] Bernhard-Reversat, F. (1989) Trees for Development in Sub-Saharan Africa: Quelques aspects des relations sol plante dans les systèmes agroforestiers et forestiers des plantes tropicaux, Laboratoire d'Écologie, ORSTOM. République Populaire du Congo, Brazzaville.

[43] Tournade, F. and Bouzillé, J.-B. (1995) Déterminisme pédologique de la diversité végétale d'écosystèmes prairiaux du marais Poitevin: Application à la définition d'une gestion agri-environnementale. Étude et gestion des sols, 2, 57-72.

[44] Sabatier, D., Grimaldi, M., Prevost, M.-F., Guillaume, J., Godron, M., Dosso, M. and Curmi, P. (1997) The Influence of Soil Cover Organization on the Floristic and Structural Heterogeneity of a Guianan Rain Forest. Plant Ecology, 131, 81-108. https://doi.org/10.1023/A:1009775025850

[45] Jiagho, E.R., Zapfack, L., Kabelong Banoho, L.P.R., Tsayem-Demaze, M., Corbonnois, J. and Tchawa, P. (2016) Diversité de la flore ligneuse à la périphérie du parc national de waza (Cameroun). Vertigo, 16, 1-26. http://vertigo.revues.org/17249 https://doi.org/10.4000/vertigo.17249

[46] Bergonzini, J.-C. (2004) Changements climatiques, désertification, diversité biologique et forêts. Silva, RIAT, Paris.

[47] Bergonzini, J.-C. and Lanly, J.-P. (2000) Les forêts tropicales. Karthala, Paris. 